\title{
The inspiration and influence of Confucian education thought to College students' personality education and shape
}

\author{
Xiaofei Wang ${ }^{1}$, Xiaolin Tian ${ }^{2, *}$ \\ ${ }^{1}$ Hainan Medical University, China \\ ${ }^{2}$ Hainan College of Economics and Business, China \\ *Corresponding author
}

Keywords: Confucian education thought, College students, Personality education, Personality shaping, Impact.

\begin{abstract}
As the main Chinese traditional ethics, Confucian ethics is that we can learn from today and take advantage of valuable resources. With the rapid development of modern society, especially the establishment of China's socialist market economic system, diversification of the market economy led to a diversification component orientation and moral values, moral concepts of university students has also been an unprecedented impact on college students ideological and political education has also suffered unprecedented challenges. On the basis of Confucian ethics dig a rich educational resources, combined with the ideological and political problems in the field of contemporary college students, based on the principle of inheritance critically discusses the Confucian ethics of contemporary ideological and political education of college students in the modern value.
\end{abstract}

\section{Introduction}

At present, our country social economy and culture are in the stage of "transformation". Due to the concept of western culture and the impact of the phenomenon and influence people's outlook on life, values and ideals common must change, is embodied in some people to "self" as the center, the lack of social sense of responsibility and mission, money worship, hedonism, individualism growing spread, steep profits become part of people's life ideal, interpersonal relations apathy, gap, etc [1]. Under the influence of social environment, university college students, there are some worrying phenomenons. One is the lack of social responsibility and public spirit, in the part of students to "self" as the center, lack of care and understanding to others, the lack of help others, selfless dedication spirit. Second, some college students lack of ideal life, weak, bad, think learning just for the sake of personal future, lack of lofty ideals, short-sighted, muddle along [1]. Three is a weak concept of collectivism, individualism is relatively serious, and some students are too pursuing the realization of self-worth, lack of collective sense of honor. Four is part of the students to pursue high consumption, towards hedonism, money worship, wear, with exquisite "famous brand", which, comparing the wind of popular.

When talking about how to alleviate the concern of social phenomenon, and profound Confucian management wisdom is indicating a bright road for us. Among them, the significance of reference to the Confucian way of cultivates one's morality especially [1]. This article from the perspective of college students, combined with the Confucian management wisdom of cultivate one's morality, discuss its enlightenment to college students develop healthy personality. 


\section{The main problems existing in the education of contemporary university students}

For a long time we have attaches great importance to college students' ideological and political education work, efforts to the ideological and political education of college students build a good atmosphere, through our unremitting efforts, the contemporary university students' ideological and political education work is quite productive, contemporary college students' mainstream ideology, active, stable, healthy and upward relative to other social groups, its overall quality shows its advantages [2]. But we also want to see, with the development of the market economy and the thought in the field of open, also brought the western ideology and culture in the decadent ideology, values and way of life such as erosion of people's thoughts, especially being active; students groups are especially good at accepting new things. Contemporary college students' ideological and moral field, there are some contradictions and problems, mainly displays in:

College students' moral level drops debase the interpersonal relationship. At present, the social environment is ramifications. From the world, the world today are developing towards the direction of political multi-polarization, economic globalization; Domestic, our country opening to the outside world is also continuously expand and deepen, economic interests, life style and employment form toward diversified development, also affected college students' ideology and value orientation also gradually tend to be diversified [2]. And along with the western capitalist culture flooding, with thought and way of life in our country outstanding traditional culture thought especially Confucian moral education thoughts is in the middle of a relatively weakened trend, cultural nihility and weakening moral ideas spread to develop. This creates some seriously distorted the value orientation of college students, pragmatism, utilitarianism and money worship, hedonism and egoism, they gradually accepted by many people, and as a human behavior and evaluate people's behavior is in line with the ethics of the only standard [1]. Some college students exist in different degrees of fuzzy ideal and faith, distortion value orientation, the good faith consciousness, the arduous struggle spirit desalination, these lead to a drop in college students' moral level, all areas have problems, especially in interpersonal exchanges increasingly philistinism and utilitarian.

In this small society in colleges and universities, the interpersonal communication is a necessary condition for the existence and development of the college students, solidarity and fraternity, vigor of interpersonal environment, the most is good for college students to form and develop healthy personality traits [2]. Some college students are in the process of communication such as the purpose, ideas, want to make oneself was improved and progress through communication, the right, but if too much too much to consider personal desire of exchanges, interests would be able to realize and achieve, what are the chances of implementation, etc. , it is easy to corrosion by mistakes such as money worship and utilitarianism thought, make personal contacts with its strong utilitarian color.

Patriotism lack and lack social responsibility of college students. The contemporary society, on the one hand, peace and development are the themes of The Times, but due to the media of misleading the outside world, many college students only see one side of the world peace and ignore the emotion increased in the process of globalization, patriotic feeling [3]. On the other hand, in the tide of globalization, the increased awareness of the global village, all of these impact the traditional concept of national sovereignty and national geographic concept, make the country borders blur, national consciousness weakening, some university student's consciousness of national sovereignty has subsided, patriotic feeling increasingly weakened. Many college students in the process of globalization complex growing in the world, some people think of themselves as "citizens of the world". College students the opportunity to contact with foreign culture increased, attention and contact this time reduces the national culture.

In addition, the popularity of the Internet, change the way of college students' life style, behavior, also makes the college students' national and national consciousness, national traditional face challenges. Western hostile forces have been using Internet to college students' ideological infiltration, induction of college students' departure from the normal values [3]. Can network without borders, across time and space use to restrict the freedom of the cases, the salient features to enhance the consciousness of college students within easy reach of the outside world, but also make the national consciousness and national consciousness among the college students' ideological slowly 
fade out even banished, as the national consciousness and national consciousness desalination more serious consequences is the college students' national identity and patriotic feelings gradually fade.

College students' moral personality is not sound; the psychological bear ability is poor. Now of the rapid economic development, science and technology is developing rapidly, some foreign culture and national culture gradually mutual fusion and the exchange, although every field in China attaches great importance to the ideological and political education of college students, from the various ways to the education of socialist core values of college students, however, some students in the preliminary understanding, to master the correct values, the understanding of the world, there is still a moral cognition and moral behavior appear deviation phenomenon, cannot be well disciplined, cause between theory and practice, moral education become a mere formality [3]. Part of the college students' morality is not strong enough, practice consciousness is poorer, as though we all know to "respect elders", "pay attention to public health" the basic moral requirements, some college students on the bus, see young and old get on the bus, still turning a blind eye.

According to the survey, college students' evaluation standard of success for individual economic value. The vast majority of college students' thought moral accomplishment is very important, but the behavior choices tend to follow the crowd; Self-evaluation of the current college students' ideological and moral standards, think they basically do not have faith, money worship ideas and selfish thoughts, contemporary college students significantly positive utility, but most of the students still can't use the ideal moral value goal to guide practice.

\section{The Education value of Confucian ethics thought to contemporary college students}

Confucius advocated "benevolence" as the moral cultivation and moral practice, to strengthen the weak link of the college students' ideological and moral education in colleges and universities in our country, cultivate noble ideological and moral quality of contemporary university students, guiding them consciously abide by it means respect, courtesy and honesty, diligence and self-improvement, and dedication to unity, friendly, the basic moral norms, improve the overall cultural quality of contemporary college students, the personal ideal and struggle is incorporated in the common ideal and struggle of the masses of the people, reflect their own value in society, has direct practical significance [4].

Confucian ethics is helpful to improve college students' moral cultivation. Communication as a social existence and ethical culture are closely related [4]. In today's era of diversified values, college students as the most active group, the outlook on life values reflected in such aspects as personality characteristics, how poor college students with different family circumstances, different growth environment, different outlook on life values of college students live in harmony, exchanges between the Confucian ethics provides a theoretical reference for us.

Confucian ethics thought to help college students cultivate the spirit of patriotism. Confucian ethics will be specified as one of the most important code of ethics of the patriotic, Confucian advocates "mind world", "taking the interests of the whole country, the society" as the behavior standard of value, everyone should be concerned with state affairs, for the country's big conscientious, for national independence, social stability and national prosperity all their dedication, this is the sublimation to personality traits, such as integrity, integrity level [4]. Mencius advocate people to cultivate noble integrity, think with it, struggle for the ideal of noble, and are as a person. Safeguarding national dignity and independence, and even for the people and the spirit of sacrifice is the important content of integrity. Confucianism advocates the mind world, determined to patriotic concept; to cultivate students' patriotic feelings plays an important role.

Confucian ethics thought to help college students in moral practice. To realize the lofty ideal we must have a positive attitude towards life. Confucian ethics advocated by the positive enterprising spirit in today's should carry forward, become a strong spiritual power of socialist modernization is an important part of. Contemporary college students should be more to motivate yourself, with the heart of the positive efforts to achieve their lofty ideal [5]. Contemporary college students should maintain their own personality independence to care about how to establish the social order of procedural justice. Really build on knowledge as the standard values, establish the authority and the dignity of 
the academic and knowledge itself, efforts to develop the students' ability of self moral cultivation, train their creative and make their life in the future to make meaningful choices [2].

College students should strengthen their own moral practice ability and the improvement of moral cultivation. On the one hand, the school shall regularly organize students to participate in social practice activities, help students to walk into society, knowledge society in an all-round way, correctly treat the life, understand the national conditions, guides them to correct a comprehensive understanding the problems existing in the development of the socialist market economy, to improve their level of moral practice. On the other hand, college students should realize the importance of their own moral accomplishment. With the essence of the traditional culture of the Chinese nation to requirements and specifications, to motivate yourself with deeds model character of the hero, with his own moral practice to reflect on themselves, constantly self moral cultivation education [5]. Through the moral behavior in the practice, enhance your ability to distinguish between rights and wrong, distinguish between good and evil, so as to motivate themselves to improve their own moral accomplishment of interest.

\section{The practical significance of the Confucian ideal personality of contemporary college students}

A nation without an inspiring spirit and lofty character can't stand proudly in the family of nations. "National education need to make a food, the national spirit education need more students' national spirit. Contact today's reality, targeted to discover the excellent heritage of national spirit, to enlighten education of contemporary college students, to cultivate shape the good qualities of contemporary college students, cultivate their noble sentiment, set up perfect personality, and make them become qualified builders and successors.

To cultivate the "self-reliance" spirit of college students. Confucian ideal can inspire students succeed in, the journey of contributing to society, strive forever. Contemporary college students on the way to success, especially need this spirit to arm themselves, they should not only learn the theoretical knowledge, but also in practice of long-term hard training, learning to constantly update knowledge, to be too old, too old to learn. Perseverance in the hard life is positive enterprising, vigorous and forever forward [6].

The "Hold world with virtue" spirit of the college students. Confucian ideal can help strengthen the consciousness of tolerant of contemporary university students, if the open valley, generous gracious to understand people, care and understanding [6]. Only in this way can all the music group, is harmonious to get along with people, unite as one do a good job.

Warning college students should have the spirit of "the world". Confucian ideal can inspire their patriotism, consciously in the world, countries as own duty, active in the great national revival, as a contemporary college student righteousness overcome lust, is a male asked people to go to private, concerned about the overall interests, devoted to national, ethnic common cause [6].

To cultivate the "industrious and frugal" spirit of college students. Confucian ideal can inspire their love Labor, respect for working people, and cherish the good quality of work, become a new generation of self-reliance and hard struggle [7]. Industrious and frugal is the concentrated reflection of our country labor people's qualities, is the basis of our national power development, need, not only in the past of the Chinese nation had a very positive impact on the progress of civilization, and in the construction of socialist material civilization and spiritual civilization today, still has its real value which cannot be ignored.

To cultivate the "see leith righteousness" spirit of college students. Confucian ideal can guide contemporary college students correctly handle the relationship between ethics and money, consciously resist the erosion of money worship and make new contributions to combat corruption and build a clean government [7].

To cultivate the "universal love" spirit of college students. Confucian ideal can inspire them to adhere to the "people-oriented", love the people, "serve the people wholeheartedly" as their own life goals, work hard [7]. Contemporary college students are the people with sweat made, the people are their own food and clothing parents, want to use practical action to return the people, social returns, this needs to develop with "humanity" spirit, consciousness of compassion to the people. 


\section{Summary}

Confucian ethics thought has formed in the one thousand years of continuous development of the Chinese nation's unique culture and spirit, is the Chinese nation different from other national moral symbol, is our unique "resource" of the Chinese nation. Today in the inheritance of Confucian ethics thought modern value and mining process, we must deeply mining arrange, effective use of, have to see, in the Confucianism, the many ideological and political education for college students have negative effects, such as despise labor, grade and junior, feudal superstition negative values. Therefore, we should use historical materialism viewpoint, absorb excellent achievements of the Chinese traditional culture, rejecting dross and antiquated. Only do not limited, and advancing with The Times, blaze new trails, to expand and enrich the contemporary ideological and political education, service for ideological and political education in the new period, to serve socialist modernization construction.

\section{References}

[1] L.S. Zhang, The combination of the theory of Confucian ethics and moral education of contemporary university students, Hunan: Hunan agricultural machinery, 2008, vol. 7, pp. 32-36.

[2] H.M. Guo, The Confucian management thinking and its enlightenment on modern students' management, Journal of Shandong institute of manager, 2008, vol. 4, PP. 10-14.

[3] Y.Y. Zhang, The ancient Chinese Confucianism and college students' ideological and moral cultivation, Journal of Anhui agricultural university (social science edition), 2012, vol. 2 pp. 26-28.

[4] Q.Z. Xia and K.Y. Han, Confucian theory "way to cultivate one's morality" in the role of ideological and moral education, Journal of Jinan university, 2001, vol. 3, pp. 21-25.

[5] Ch.H. Li, The Confucius thought and education of contemporary college student's management, BBS education literature, 2010, vol. 9, pp. 43-47.

[6] L.Q. Li, Talking about Confucianism shape healthy personality of college students, Tribune economic research, 2009, vol. 3, pp. 73-77.

[7] Y.Sh. Zheng, Theory of culture and personality, Journal of Shaanxi normal university: philosophy and social science edition, 2013, vol. 8, pp. 54-56. 